\title{
Economic Management Innovation of Power Enterprises in the Market Economy System
}

\author{
Wang Qiang \\ State Grid Cangzhou Power Supply Company \\ Cangzhou, Hebei, 061000, PRC
}

\author{
Qu Yi'ang \\ State Grid Electric Power Hebei Company \\ Dongguang Power Supply Branch-company \\ Cangzhou, Hebei, 061600, PRC
}

\author{
Wang Mei \\ State Grid Electric Power Hebei Company \\ Dongguang Power Supply Branch-company \\ Cangzhou, Hebei, 061600, PRC
}

\begin{abstract}
In the context of global economic integration today, competition among industries has become increasingly intense. How to seek new competitiveness in such a fierce competition has become the focus of all parties. Power enterprises are greatly affected because of the imperfection of their management system in the production cost control, operation management, evaluation mechanism, technical and economic evaluation mode and safety awareness. In this sense, it is necessary to increase the innovation of economic management of power enterprises, so that they can better meet the requirements of modern development. To this end, the author, combined with years of practical work, proposes that it is needed to comprehensively enhance the economic management of power enterprises and shift their focus to economic efficiency, so as to maximize profits in the market according to the law of economics.
\end{abstract}

Keywords-market economy system; power enterprises; economic management innovation

\section{INTRODUCTION}

Power enterprises do not have many competitors in China, and most of these power enterprises are large-sized. However, power enterprises have to face global competition in the current market globalization. And in the process, power enterprises should be able to adjust the corresponding business strategy according to the market conditions in a timely manner to avoid the funds or operational difficulties caused by improper operation. When carrying out economic management, power enterprises should be able to apply innovation on their management modes and concepts according to market conditions. On the one hand, the development of the market economy makes the power enterprises face competition from all over the world; on the other hand, the power enterprises in the market economy environment have a vast market. Therefore, when power enterprises carry out some economic activities, they need to bring forth new ideas to their economic management mode based on market trends, so as to promote their steady progress in the market economy. In the face of the operation and management situation of power enterprises now, we should continue to explore and discover to find out the existing shortcomings and problems; combined with the actual situation of power enterprises, scientific and objective attitude should be used to explore the way for the future development of power enterprises[1-2]. Improving the efficiency of economic management of power enterprises is of great significance to promote the development of China's national economy, and thus it is very urgent to do innovation on the economic management of power enterprises.

\section{MARKET ECONOMY SYSTEM}

With the continuous development of society, the commodity economy has rapidly developed. An economic system which gives priority to the market gradually forms on this basis. It greatly differs from the capitalist economic system because it has the characteristics of being very liberal and open. In the market economy system, government departments play the role of regulation, rather than directly involving in the market. The allocation of resources is entirely determined by the subject market. But the market economic system must be consistent with the socialist characteristics of China and provide very good vitality for the country's economic development. Although the system is very powerful in some aspects, it also has many unfavorable factors which will lead to very serious pressure on market competition. As the pillar industry of the country, power enterprises also suffer huge impacts of the market economy in the course of development [3]. Therefore, in order to better adapt to the demands of modern development, power enterprises must carry out economic management mode innovation to enhance their management, so that they can develop better and make an important contribution to the national economic construction.

\section{REASONABLE CONTROL OF THE PRODUCTION COST OF POWER ENTERPRISES}

The reasonable control of the production cost of power enterprises requires that the production cost should be reduced as much as possible under the premise of ensuring income generation, so as to maximize the profit. The work can be carried out specifically from the following aspects. The first one is to refine cost control and reduce costs. The power 
enterprises can divide all costs into two categories: the relative fixed cost and variable cost. Wages, overwork subsidies, depreciation of equipment, water, electricity, heating and other expenditures should be regarded as the enterprise cost. The refinement of cost items can control costs and improve resource utilization. The second one is to compress inventory and enhance material control. Power enterprises can rebuild a business process for the receiving, dispatching, storage and use of raw materials, forming a set of effective management system. The quota management of inventory can avoid the three kinds of risks brought by huge inventory (the expiration risk, price risk and safety management risk), which can save the cost of inventory and reduce the capital occupation.

\section{STRENGTHENING THE OPERATION AND MANAGEMENT OF POWER ENTERPRISES}

The modernization of production and operation management requires detailed management and quantitative management of economic and technical indicators. Power enterprises should decompose the economic indicators, allocate them to the various units and assign specific persons to the monthly production plan, so that the economic indicators and the economic interests of each person are closely linked; at the same time, corresponding summary as well as rewards and punishments should be conducted according to the completion of the monthly economic indicators in a timely manner to effectively mobilize the enthusiasm of the staff. The combination of each person's interests and production indicators and assessment in a regular time can ensure that the indicators can be completed on time, achieving the improvement of personal production efficiency [4].

\section{Perfecting the ENTERPRise management AND ASSESSMENT MECHANISM}

In order to further improve the standardized management of power enterprises, perfect the work system, promote enterprise development and improve economic efficiency in the current market environment, the author thinks that power enterprises should pay attention to the following two points when they carry out comprehensive management and assessment. One is the basic principle of management and assessment. Taking the economic benefit as the center, power enterprises should implement the internal simulation market. The method and content of the examination should be fair and accurate, and can objectively and comprehensively reflect the overall management level of the grass-roots units. The establishment of indicators and the evaluation items should stress the key points and be easy to operate. The other is the basic content of management and assessment. The basic content should be composed of three parts. (1) Economic benefit evaluation: power enterprises should conduct assessment in accordance with the completion situation of internal profits listed in the implementation measures of the power simulative market, and the level of internal profits should be the basis to assess the performance of power enterprises. For these which do not belong to the power generation and supplying units of an enterprise, the enterprise, in light of specific conditions, shall assess them separately from the two aspects -- profit realized and expenses reduced. (2) Enterprise operation monitoring: The monitoring of enterprise operation should be carried out from four aspects, namely the Party Committee's guarantee supervision, staff's democratic supervision, capital construction's inspection and supervision and auditing supervision. (3) Enterprise management evaluation: According to the characteristics of power enterprises, the enterprise management should be evaluated by the way combining safety management evaluation and overall management evaluation. Because safety is of special importance in the production of power enterprises, safety management evaluation should be kept. Moreover, the enterprise should conduct a comprehensive evaluation, according to the assessment of departments in safety objectives, security checks, risk elimination and other aspects. The organic combination of the three aspects above builds a complete comprehensive management and assessment system for grass-roots units. Hundred-mark assessment system can be used, while the assessment methods and procedures as well as rewards and punishments should be clearly defined.

\section{Perfecting the technical eCOnOmy Model EVALUATION OF POWER ENTERPRISES}

Based on the characteristics of the power industry, the following 8 indicators are selected to evaluate the comprehensive economic efficiency of power enterprises in the electricity market. (1) Operating scale. Main indicators include installed capacity, total assets, power sale quantity, sales revenue and single-machine capacity. Generally speaking, large enterprises can achieve economies of scale. The installed capacity and total assets of a power plant can be regarded as a main indicator that can reflect the scale of the power plant, and the single-machine capacity provides an effective supplementary instruction to the unit structure. Power sale quantity and sales revenue directly reflect the business scale of an enterprise. (2) Unit efficiency and reliability. This main indicator includes unit thermal efficiency, coal consumption rate, grade availability, forced outage rate, etc. (3) Operating capacity. There are many indicators reflecting operating capacity, usually based on financial statements. From the efficiency of capital flow, the main indicator includes turnover of current assets and total assets turnover. (3) Capacity of operating safely. Whether the enterprise is operating safely or unsafely reflects its actual viability, which can be evaluated from three aspects: the enterprise capital structure, short-term debt paying ability and long-term solvency. The indicator mainly includes the component ratio of entity capital, equity ratio, the current ratio, the quick ratio, the assets liabilities ratio and the amount of interest earned (the ratio of interest payments). (5) Profitability. The indicator mainly includes ratio of sales, rate of return on total assets, capital profit margin and return on equity. (6) Capital operation capability. This main indicator includes economic value added, rate of value maintaining and increasing, etc. (7) Market influence capability. This indicator mainly includes utilization time of generation equipment, and market share of generated energy, corporate social image, etc. (8) Device and equipment. The advanced degree of the existing devices and equipment in an enterprise can be reflected by the newness rate of fixed assets, the input rate of $\mathrm{AGC}$, the input rate of high-efficiency dust collector, the minimum technical output, the informatization level of the enterprise and other indicators. 


\section{STRENGTHENING THE SAFETY AWARENESS OF POWER} ENTERPRISES AND IMPROVING ECONOMIC BENEFITS

- Safety production is a systematic project needing comprehensive management. Modern security management theories and methods are various, but each of them has its advantages and disadvantages. Therefore, enterprises should select and apply management methods according to their actual situation. From the current practice of safety production management in power enterprises, units should cooperate with each other, rather than working independently without any connection with each other [5]. For example, the safety production of a power plant is a huge system project involving human, machine, environment and other links, and the problem in any link may make the whole system cannot operate safely. Therefore, it is necessary to embody safety in production, so that production, management and technological progress can coordinate with each other, realizing fostering strengths and circumventing weaknesses. Strengthening prevention and controlling from the source lies in details.

- It is needed to strengthen the equipment management to ensure the normal operation of every unit, in order to improve the safety management of power enterprises. The closed-loop link management of power equipment is to analyze and diagnose these links and then eliminate hidden dangers, achieving management in place. The "overhaul document package" management system should be implemented to strengthen the overhaul management and eliminate the potential sources of accidents. Through the full implementation of operational improvement and comparison of operation quantitative indicators, the operating level and economic indicators of power enterprises can be improved. At the same time, it is essential to establish a rewards and punishments system for "3 maintenance" safety management, carry out special investigation and management of hidden troubles, strengthen the supervision of major sources of dangers, thoroughly implement the safety production responsibility system and further standardize and improve the emergency rescue management. In addition to carrying out a variety of safety knowledge contests and organizing appraisal activities of non-violation class teams, power enterprises should also strengthen safety production training, perfect the management system and improve safety management, thereby enhancing their own economic efficiency.

- It is necessary to improve the overall quality of staff and business level to ensure safety in production. To power enterprises, the safety in production cannot be separated from human factors, and thus improving the overall quality of staff is an effective way to improve the economic efficiency. In order to ensure the effective implementation of safety operation, efforts should be made to improve the safety awareness of staff and expand their professional skills. While insisting on applying the education of safety awareness, safety attitude and safety technical knowledge on staff, power enterprises should focus on the improvement of staff's technical skills.

Power enterprises can adopt the training way combining the learning of typical experience and accident lessons with regular training of staff's basic skills. "Learning teams and groups" activities should be carried out in a systematical and designed way, aiming to improve basic skills of operating personnel, including equipment inspection and maintenance, eliminating security risks, switching operations, handling accidents, etc. Enterprises also need to conduct regular workshops to discuss and summarize analysis, judgment and treatments of common failures. Training about the relevant knowledge of new equipment, new technologies and automatic devices is also important. The purpose of these activities is to create a good learning environment for staff, forming benign competitive atmosphere featured by emphasizing business learning and business competition. Food training can improve staff's overall quality and their business capacity, which is an effective way to reduce the risks, avoid major accidents and improve the economic efficiency of power enterprises.

\section{CONCLUSION}

To sum up, as a complex synthesis in the market economy environment, the power enterprise is inevitably stepping to the marketization. Taking the road of marketization and pursuing the maximum profits has become the inevitable pursuit of power enterprises for the long-term survival. However, the power industry is rising while the planned economy is shifted to the market economy [6], and thus there are still many deficiencies in its development process. Only by comprehensively enhancing the economic consciousness, transforming the focus of power enterprises to the economic efficiency and pursuing profit maximization in the market according to the laws of economics can the power enterprises stand in an invincible position in the market economy.

\section{REFERENCES}

[1] Chen Lifang, Ru Jianwen, Chen Yunyan, et al. Problems in Electric Power Marketing and Analysis of Refined Strategy [J] Management \& Technolosy of SME, 2015 (2): 31-32.

[2] Ji Qin. Talking about the Role of Electricity Marketing and Electricity First-rate Service in Marketing [J]. Technology and Enterprise, 2014 (17): 108 .

[3] Wei Dinglei. Discussion on the Construction of Electric Power Marketing Culture and the Development of Electric Power Marketing in the New Period [J]. Managers' Journal, 2013 (25): 262.

[4] Zeng Ming. Commercial Operation of Power Industry and Power Market, [M]. China Electric Power Press, 1998.

[5] Yu Fengling. Problems and Countermeasures in Economic Management of Power Enterprises [J]. Enterprise Reform and Management, 2015,06.

[6] Ma Li. Economic Management Innovation of Power Enterprises under the Market System [J]. Operating and Management, 2013, 5 (45) 